\title{
Effects of harvesting stages on yield and nutritional quality of African eggplant (Solanum aethiopicum L.) fruits
}

\author{
Theodosy J. Msogoya*1 , Ramadhani O. Majubwa ${ }^{1}$ and A.P. Maerere ${ }^{1}$ \\ ${ }^{1}$ Department of Crop Science and Production, Sokoine University of Agriculture, P.O Box 3005, Morogoro, \\ Tanzania. \\ *Corresponding author: timsogoya@yahoo.com
}

Original submitted in on 19th February 2014. Published online at www.m.elewa.org on $30^{\text {th }}$ June 2014. http://dx.doi.org/10.4314/iab.v78i1.1

\begin{abstract}
Objective: Farmers often harvest African eggplant (Solanum Aethiopicum L.) fruits at different stages of fruit maturity. The influence of these harvesting practices on fruit productivity and nutritional quality is not known. This study was conducted to determine the effect of harvesting stages on yield and nutritional quality of African eggplant varieties.

Methodology and results: The experiment was laid out in a split plot arrangement in a complete randomized block design with three replications. Three African eggplant varieties (Tengeru white, AB2 and Manyire green) and three harvesting stages (1,2 and 3 ) were used as main plot factor and sub plot factor, respectively. Harvesting stage 1 (immature fruits) was characterized by fruits with non-shiny peel, harvesting stage 2 (mature fruits) was characterized by fruits with shinny peel and harvesting stage 3 (overmature fruits) was characterized by fruits with yellow coloration at the bottom. Fruit yield was assessed based on number and weight of fruits per plant while fruit nutritional quality was assessed in the laboratory based on carbohydrate, fibres, calcium, potassium, magnesium, phosphorus, iron, $\beta$-carotene and ascorbic acid contents. The collected data were subjected to analysis of variance using MSTATC statistical software. Treatments mean separation was conducted based on Student-Newman Keuls at $P<5 \%$. Results showed that yield in number of fruits per hectare decreased while yield in metric tons per hectare increased with fruit development stages. Varieties Tengeru white and $A B 2$ had the highest yields based on metric tons at harvesting stage 2 while Manyire green had the highest yield at harvesting stage 3 . Carbohydrate and fibre contents increased while ascorbic acid, $\beta$-carotene and most minerals decreased with fruit development stages.

Conclusion and application of results: This study recommends harvesting immature fruits for high vitamin and mineral contents and delayed harvesting for the highest yield. As yield and nutritional quality trends vary with varieties, further studies are required to determine the effect of harvesting stages on yield and nutritional quality of different varieties of African eggplant.
\end{abstract}

Key words: Yield, Nutritional quality, Harvesting stages, Africa eggplant

\section{INTRODUCTION}

Background information: African eggplant (Solanum aethiopicum L.) is one of the indigenous vegetables that play a significant role in both subsistence production and income generation among rural and urban resource-poor communities in Tanzania (Chadha, 2006). This crop is notable for high yield of about 67 tons per hectare and high market potential (National Research Council, 2006). Fruit colour, shape, size and flavour are the most perceivable quality attributes of African 
eggplant fruits (Hornal et al., 2007). Compared with most fruit vegetables like tomato, African eggplant fruits have relatively higher, carbohydrate $(7.2 \mathrm{~g} / 100 \mathrm{~g})$, fibres $(2.0 \mathrm{~g} / 100 \mathrm{~g})$, calcium $(28$ $\mathrm{mg} / 100 \mathrm{~g})$, iron $(1.5 \mathrm{mg} / 100)$ and considerable amount of $\beta$-carotene $(0.35 \mathrm{mg} / 100 \mathrm{~g})$ and ascorbic acid $(8 \mathrm{mg} / 100 \mathrm{~g})$ (Hornal et al., 2007). Mature fruits of African eggplant are either boiled or roasted with onions and tomato, and consumed with stiff porridge or cooked rice. Alternatively, the fruits are boiled with various vegetables, and then mixed with already boiled meat, chicken or fish to make a soup popularly known as "mchemsho". Maturity stage at harvest is among the most important factors that influences yield and nutritional quality of fruits and vegetables (Kader, 1986; Kader, 2008). In Tanzania, growers of African eggplant are advised to harvest the fruits before the skin becomes tough and original varietal

\section{MATERIALS AND METHODS}

Description of study site and materials: A field experiment was conducted at Sokoine University of Agriculture (SUA) located at 6०05' South and 35037' East. The University lies at an altitude of $525 \mathrm{~m}$ above sea level and has warm tropical climate with an average annual rainfall of $600-1000 \mathrm{~mm}$. During the field experiment period, the area experienced a mean rainfall and temperature of $85.38 \mathrm{~mm}$ and $25.4^{\circ} \mathrm{C}$, respectively. The area has fertile red sand-clay soil with a pH of around 6.0. Three popular varieties of African eggplant namely Tengeru white (early maturing), Manyire green (late maturing) and $A B 2$ (early maturing) were used in this study. Seeds were collected from Asian Vegetable Research Development Centre Africa Program (AVRDC-AP) in Arusha, Tanzania. The seeds of these varieties were sown in a nursery composed of a mixture of sandy loam soil and farmyard manure at the ratio of 2 to 1 by volume, respectively. The seeds germinated within two weeks and seedlings were managed throughout the nursery period by irrigating twice a day during the first two weeks and once a day in the last four weeks of the nursery period. Applications of Selecron $®$ (Profenofos) insecticide and Ridomy|ß (Metalaxyl+Mancozeb) fungicide at the rate of $1 \mathrm{~mL} / \mathrm{L}$ and $2 \mathrm{~g} / \mathrm{L}$ were carried out after every two weeks for the control of insect and parasitic fungal attacks, respectively. The seedlings were transplanted in the main field six weeks from the date of sowing. The experimental field previously grown with maize was ploughed and harrowed using a tractor and further colour changes (AVRDC, 2003), which is estimated at 70 - 90 days from the date of sowing depending on varieties and weather conditions (National Research Council, 2006). Delayed harvesting leads to fruit over-maturity and colour development while still on the plants (Hornal et al., 2007, Kader, 1996). Conversely, fruit harvest at immaturity stage results in faster shrivelling and fruit susceptibility to mechanical damages (Kader, 1999). Growers in Tanzania harvest African eggplant based on fruit size with fruits often consisting of immature, mature and over-mature fruits. Little is known about the influence of such harvesting stages on yield and nutritional quality of popular local varieties of African eggplant. The objective of this study was to assess the effect of harvesting stages on fruit yield and nutritional quality of African eggplant.

levelled using hand hoes. Small ridges were then prepared across the slope to improve drainage and facilitate irrigation. During ridge preparation, farmyard manure was incorporated at the rate of $18 \mathrm{~L} \mathrm{per} \mathrm{m}^{2}$ of a plot. The seedlings were transplanted in December 2010 at spacing of $75 \mathrm{~cm} \times 75 \mathrm{~cm}$. NPK (15:15:15) fertilizer was applied two times during the experimental duration. The first basal application at a rate of $5 \mathrm{~g} / \mathrm{plant}$ was done two weeks after transplanting the seedlings while the second basal application was done at the flowering stage using the same application rate. The field was irrigated after every fertilizer application. Subsequent irrigation during the dry period was carried out twice a day in the first two weeks after transplanting and thereafter it was done once per day. Field pests were managed using Selecron $®$ (Profenofos) insecticide and Ridomyl $\circledast$ (Metalaxyl+Mancozeb) fungicide at the rate of $1 \mathrm{ml} / \mathrm{l}$ and $2 \mathrm{~g} / \mathrm{l}$, respectively. The spraying was conducted once per two weeks during the dry season and once per week during the rainy season.Experimental designs: The field experimental design was a split plot in a complete randomized block design with three replications. Three African eggplant varieties (Tengeru white, Manyire green and $A B 2$ ) and three harvesting stages (1,2 and 3 ) were used as main factor and sub factor, respectively. The harvesting stages were defined based on fruit peel colour and number of days to fruit harvest (Table 1). The fruit physical characteristics of these varieties are shown in Figure 1. 
Msogoya et al. J. Appl. Biosci. 2014. Effect of harvesting stages on yield and nutritional quality of African eggplant (Solanum aethiopicum) fruits.

Table 1: Descriptive characteristics of fruit harvesting stages of African eggplant

\begin{tabular}{llll}
\hline Variety & Harvest Stage & Fruit-peel colour & $\begin{array}{l}\text { No. of days from planting to } \\
\text { 1st harvest }\end{array}$ \\
\hline \multirow{2}{*}{ Tengeru white } & 1 & Non shining cream white & 72 \\
& 2 & Shiny cream white & 83 \\
\multirow{2}{*}{$A B 2$} & 3 & $25 \%$ orange-yellow colour & 90 \\
& 1 & Non shining light-green & 72 \\
& 2 & Shiny white & 83 \\
\multirow{2}{*}{ Manyire green } & 3 & 25\% orange-yellow colour & 90 \\
& 1 & Non shining light-green & 78 \\
& 2 & Shiny dark-green & 85 \\
\hline
\end{tabular}

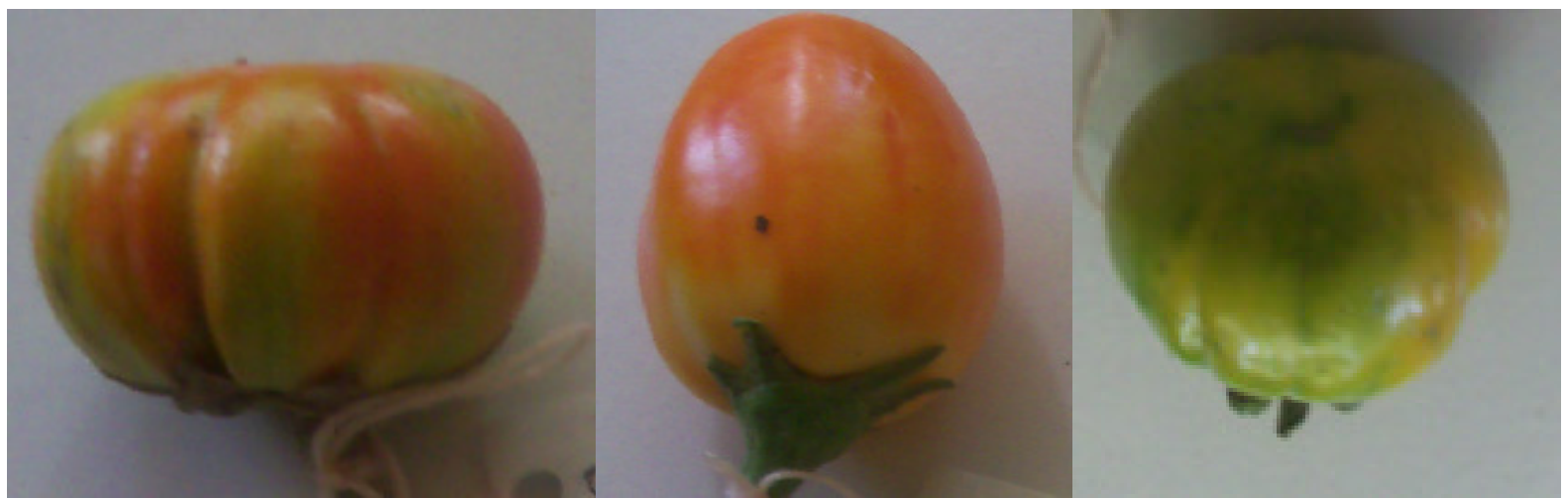

Figure 1: Fruit physical characteristics: Left - Tengeru white, Middle - AB2 and Right - Manyire green

Data collection and analysis: Fruit yield was assessed based on the number and weight of fruits per plant. The harvested fruits were weighed using an analytical balance (Sartorius AG Gottingen BP121S, Germany). On the other hand, nutritional quality was analyzed based on carbohydrate, fibres, calcium, potassium, magnesium, phosphorus, iron, $\beta$-carotene and ascorbic acid contents using nine fruits per each harvesting stage. Fruit crude fibre, ascorbic acid, ash, mineral, carbohydrate and $\beta$-carotene contents were determined according to Seki (1990). Analysis of variance was performed using an MSTAC Data Analysis Software. Treatment mean separation was carried out based on Student-Newman-Keuls at $\mathrm{P}<$ 0.05 .

\section{RESULTS}

Effect of harvesting stages on fruit yield: The three African eggplant varieties differed significantly $(P<0.05)$ in respect to yield (Table 2) with variety Tengeru white having the largest number of fruits of $28.03 \times 10^{5}$ fruits/ha followed by Manyire green and $A B 2$ with $25.05 \times 10^{5}$ and $18.88 \times 10^{5}$ fruits/ha, respectively. However, Manyire green had the highest fruit weight of $53.62 \mathrm{t} / \mathrm{ha}$ followed by Tengeru white and $A B 2$ with 47.28 and $40.19 \mathrm{t} / \mathrm{ha}$, respectively.

Table 2: Effect of variety on yield and fruit size of African eggplant fruits

\begin{tabular}{lll}
\hline Variety & Yield/ha & \\
\cline { 2 - 3 } & Number of fruits $\times 10^{5}$ & Ton $(\mathrm{t})$ \\
\hline Tengeru white & $28.03 \mathrm{a}$ & $47.28 \mathrm{~b}$ \\
Manyire green & $25.05 \mathrm{~b}$ & $53.62 \mathrm{a}$ \\
AB2 & $18.88 \mathrm{c}$ & $40.19 \mathrm{c}$ \\
Mean & 23.99 & 47.58 \\
F-test & $<0.001$ & $<0.001$ \\
CV (\%) & 2.3 & 2.00 \\
SE & 0.3162 & 0.301 \\
\hline
\end{tabular}

Means bearing the same letter(s) within the column are insignificantly $(\mathrm{P}<0.05)$ different according to StudentNewman-Keuls. $\mathrm{Fpr}=\mathrm{F}$ distribution probability, $\mathrm{CV}=$ coefficient of variation and $\mathrm{SE} \pm=$ Standard error . 
The harvesting stages had a highly significant $(P<0.05)$ influence on yield of African eggplant (Table 3$)$. Harvesting stage 1 had the largest fruit number of $33.01 \times 10^{5}$ fruits/ha followed by harvesting stage 2 and harvesting stage 3 with $20.68 \times 10^{5}$ and $18.27 \times 10^{5}$ fruits/ha, respectively. On the contrary, yield in metric tons per hectare was the highest in harvesting stage 2 and harvesting stage 3 with 60.78 and 60.46 t/ha, respectively while harvesting stage 1 had the lowest yield of 19.86 tha.

Table 3: Effect of harvesting stage on yield of three African eggplant varieties

\begin{tabular}{lll}
\hline Harvesting stage & Yield/ha & \\
\cline { 2 - 3 } & Number of fruits $\times 10^{5}$ & Ton $(\mathrm{t})$ \\
\hline 1 & $33.01 \mathrm{a}$ & $19.86 \mathrm{~b}$ \\
2 & $20.68 \mathrm{~b}$ & $60.78 \mathrm{a}$ \\
3 & $18.27 \mathrm{c}$ & $60.46 \mathrm{a}$ \\
Mean & 23.99 & 47.58 \\
F-test & $<0.001$ & $<0.001$ \\
CV $(\%)$ & 2.30 & 2.00 \\
SE & 0.3162 & 0.792 \\
\hline
\end{tabular}

Means bearing the same letter(s) within the column are insignificantly $(\mathrm{P}<0.05)$ different according to StudentNewman-Keuls.

The variety-harvesting stage interaction had a significant $(P<0.05)$ influence on yield of African eggplant fruits (Table 4). Variety Tengeru white and $A B 2$ showed a decreasing number of fruits per hectare from harvesting stage 1 to harvesting stage 3 while variety Manyire green showed a decreasing number of fruits per hectare from harvesting stage 1 to harvesting stage 2 and increasing number of fruits from harvesting stage 2 to harvesting stage 3 . On the contrary, yield in terms of tons per hectare for Manyire green increased from harvesting stage 1 to harvesting stage 3 whereas such yield increased from harvesting stage 1 to harvesting stage 2 and then decreased towards harvesting stage 3 for variety Tengeru white and $A B 2$.

Table 4: Interaction effect of variety-harvesting stage on yield of three African eggplant varieties

\begin{tabular}{|c|c|c|}
\hline \multirow[t]{2}{*}{ Treatment combination } & \multicolumn{2}{|l|}{ Yield/ha } \\
\hline & Fruits $\times 10^{5}$ & Ton $(t)$ \\
\hline Tengeru white $\mathrm{x} 1$ & $41.84 a$ & $23.95 f$ \\
\hline Tengeru white $\mathrm{x} 2$ & $23.05 \mathrm{e}$ & $63.07 \mathrm{c}$ \\
\hline Tengeru white $\times 3$ & $19.20 \mathrm{~g}$ & $57.82 d$ \\
\hline$A B 2 \times 1$ & $27.55 \mathrm{c}$ & $18.62 \mathrm{~g}$ \\
\hline$A B 2 \times 2$ & $18.43 \mathrm{~g}$ & $56.54 d$ \\
\hline$A B 2 \times 3$ & $10.67 \mathrm{~h}$ & $49.74 \mathrm{e}$ \\
\hline Manyire green $\times 1$ & $29.63 b$ & $18.34 \mathrm{~g}$ \\
\hline Manyire green $\times 2$ & $20.56 f$ & $65.71 b$ \\
\hline Manyire green $\times 3$ & $24.95 d$ & $74.43 a$ \\
\hline Mean & 23.99 & 47.58 \\
\hline Fpr & $<0.001$ & $<0.001$ \\
\hline CV (\%) & 2.3 & 2.00 \\
\hline $\mathrm{SE} \pm$ & 0.032 & 1.104 \\
\hline
\end{tabular}

Means bearing the same letter(s) within the column are insignificantly $(\mathrm{P}<0.05)$ different according to StudentNewman-Keuls. Numbers 1, 2 and 3 stand for harvesting stage 1, 2 and 3, respectively.

Effect of harvesting stages on fruit nutritional quality : African eggplant varieties had a significant $(P$ $<0.05)$ influence on fruit carbohydrate $(\mathrm{CHO})$ and ascorbic acid contents (Table 5). Variety Tengeru white and Manyire green had a significantly higher fruit $\mathrm{CHO}$ content of 6.804 and $6.59 \%$ compared with variety $A B 2$ with fruit $\mathrm{CHO}$ content of $5.371 \%$. Manyire green had the highest ascorbic acid content of $8.98 \mathrm{mg} / 100 \mathrm{~g}$ compared to Tengeru white and $A B 2$ with 7.67 and $7.71 \mathrm{mg} / 100 \mathrm{~g}$, respectively. 
Table 5: Effect of variety on nutritional quality of African eggplant fruits

\begin{tabular}{|c|c|c|c|c|c|c|c|c|c|c|}
\hline Variety & $\begin{array}{l}\mathrm{CHO} \\
(\%)\end{array}$ & $\begin{array}{l}\text { Ascorbic } \\
(\mathrm{mg} / 100 \mathrm{~g})\end{array}$ & acid & $\begin{array}{l}\text { ß-carotene } \\
(\mu \mathrm{g} / \mathrm{g})\end{array}$ & Fibre (\%) & $\begin{array}{l}P(\mathrm{mg} / \\
100 \mathrm{~g})\end{array}$ & $\begin{array}{l}\mathrm{Fe}(\mathrm{mg} / \\
100 \mathrm{~g})\end{array}$ & $\begin{array}{l}\mathrm{Ca}(\mathrm{mg} / \\
100 \mathrm{~g})\end{array}$ & $\begin{array}{l}\mathrm{Mg}(\mathrm{mg} / \\
100 \mathrm{~g})\end{array}$ & $\begin{array}{l}\mathrm{K}(\mathrm{mg} / \\
100 \mathrm{~g})\end{array}$ \\
\hline Tengeru white & $6.804 a$ & $7.67 \mathrm{~b}$ & & $7.57 a$ & $1.157 a$ & $31.3 a$ & $12.0 \mathrm{a}$ & $36.7 a$ & $10.1 \mathrm{a}$ & $213 a$ \\
\hline$A B 2$ & $5.371 b$ & $7.71 \mathrm{~b}$ & & $7.09 a$ & $1.262 a$ & $36.5 a$ & $10.7 a$ & $39.4 a$ & $11.0 \mathrm{a}$ & $209 a$ \\
\hline Manyire green & $6.590 \mathrm{a}$ & $8.98 a$ & & $8.14 a$ & $1.218 \mathrm{a}$ & $38.6 a$ & $17.1 \mathrm{a}$ & $65.2 a$ & $18.3 a$ & $203 a$ \\
\hline Mean & 6.255 & 8.120 & & 7.6 & 1.212 & 35.5 & 13.30 & 47.10 & 13.10 & 208.0 \\
\hline F-test & 0.008 & 0.044 & & 0.17 & 0.132 & 0.331 & 0.533 & 0.153 & 0.396 & 0.919 \\
\hline CV $(\%)$ & 8.2 & 12.20 & & 17.6 & 6.40 & 27.90 & 102.6 & 49.80 & 87.5 & 27.50 \\
\hline $\mathrm{Se}+$ & 0.172 & 0.271 & & 0.313 & 0.028 & 3.09 & 3.98 & 9.92 & 4.18 & 16.10 \\
\hline
\end{tabular}

Means bearing the same letter(s) within the column are insignificantly $(\mathrm{P}<0.05)$ different according to Student-Newman-Keuls.

Table 6: Effect of harvesting stage on nutritional quality of African eggplant fruits

\begin{tabular}{|c|c|c|c|c|c|c|c|c|c|}
\hline Harvest stage & $\begin{array}{l}\text { CHO } \\
(\%)\end{array}$ & $\begin{array}{l}\text { Ascorbic Acid } \\
(\mathrm{mg} / \\
100 \mathrm{~g})\end{array}$ & $\begin{array}{l}\text { ß-carotene } \\
(\mu \mathrm{g} / \mathrm{g})\end{array}$ & $\begin{array}{l}\text { Fibre } \\
(\%)\end{array}$ & $\begin{array}{l}P(\mathrm{mg} / \\
100 \mathrm{~g})\end{array}$ & $\begin{array}{l}\mathrm{Fe}(\mathrm{mg} / \\
100 \mathrm{~g})\end{array}$ & $\begin{array}{l}\mathrm{Ca}(\mathrm{mg} / \\
100 \mathrm{~g})\end{array}$ & $\begin{array}{l}\mathrm{Mg}(\mathrm{mg} / \\
100 \mathrm{~g})\end{array}$ & $\begin{array}{l}\mathrm{K}(\mathrm{mg} / \\
100 \mathrm{~g})\end{array}$ \\
\hline 1 & $6.202 a$ & $11.45 a$ & $9.74 a$ & $0.709 \mathrm{c}$ & $49.90 a$ & $24.90 a$ & $85.90 a$ & $21.70 a$ & $221.0 \mathrm{a}$ \\
\hline 3 & $6.318 a$ & $4.84 \mathrm{c}$ & $5.46 \mathrm{c}$ & $1.732 a$ & $29.30 \mathrm{~b}$ & $6.90 \mathrm{~b}$ & $24.80 \mathrm{~b}$ & $8.30 a$ & 199.0a \\
\hline Mean & 6.255 & 8.120 & 7.6 & 1.212 & 35.5 & 13.3 & 47.10 & 13.10 & 208.0 \\
\hline CV (\%) & 8.20 & 12.20 & 17.60 & 6.40 & 27.90 & 102.6 & 49.80 & 87.50 & 27.50 \\
\hline $\mathrm{Se} \pm$ & 0.170 & 0.331 & 0.446 & 0.026 & 3.3 & 4.540 & 7.830 & 3.830 & 19.10 \\
\hline
\end{tabular}

Means bearing the same letter(s) within the column are insignificantly $(\mathrm{P}<0.05)$ different according to Student-Newman-Keuls.

Numbers 1, 2 and 3 stand for harvesting stage 1, 2 and 3, respectively. 
The harvesting stages had a highly significant $(P<$ $0.05)$ influence on ascorbic acid, $\beta$-carotene, fibre, phosphorus $(\mathrm{P})$ and calcium $(\mathrm{Ca})$ contents of African eggplant fruits (Table 6). Similarly, the harvesting stages significantly $(P<0.05)$ influenced iron $(\mathrm{Fe})$ and magnesium (Mg) contents of African eggplant fruits. Ascorbic acid and $\beta$-carotene contents were the highest in harvesting stage 1 with $11.45 \mathrm{mg} / 100 \mathrm{~g}$ and 9.74 $\mu \mathrm{g} / \mathrm{g}$, respectively followed by harvesting stage 2 with $8.08 \mathrm{mg} / 100 \mathrm{~g}$ and $7.6 \mu \mathrm{g} / \mathrm{g}$ and harvesting stage 3 with $4.84 \mathrm{mg} / 100 \mathrm{~g}$ and $5.46 \mu \mathrm{g} / \mathrm{g}$, respectively. Phosphorus, iron and calcium contents were significantly $(P<0.05)$ higher in harvesting stage 1 with 49.9, 24.9, 85.9, 85.9, and $151 \mathrm{mg} / 100 \mathrm{~g}$, respectively compared with the harvesting stage 2 with $27.20,8.0$, and $30.70 \mathrm{mg} / 100 \mathrm{~g}$ and harvesting stage 3 with $29.30,6.90$, and 24.80 $\mathrm{mg} / 100 \mathrm{~g}$. On contrary, the fibre content was the highest in harvesting stage 3 with $1.732 \mathrm{mg} / 100 \mathrm{~g}$ followed by harvesting stage 2 and harvesting stage 1 with 1.196 and $0.709 \mathrm{mg} / 100 \mathrm{~g}$, respectively. The variety- harvesting stage interaction had a significant $(P<0.05)$ influence on carbohydrate and ascorbic acid contents (Table 7). Variety Tengeru white showed increasing fruit carbohydrate content from harvesting stage 1 to harvesting stage 2 with 6.197 to $7.132 \%$, respectively. On the other hand, variety Manyire green and $A B 2$ showed constant carbohydrate contents throughout harvesting stages. Variety Tengeru white, $A B 2$, and Manyire green showed a decreasing ascorbic acid content from harvesting stage 1 to harvesting stage 3 . The variety-harvesting stage interaction had also a significant $(P<0.001)$ influence on beta-carotene content. Variety Tengeru white and $A B 2$ showed increasing beta carotene content from harvesting stage 1 to harvesting stage 2, which decreased from harvesting stage 2 to harvesting stage 3 . On the contrary, variety Manyire green showed a decreasing beta-carotene content from harvesting stage 1 to harvesting stage 3 . 
Table 7: Interaction effect of variety-harvesting stage on nutritional quality of African eggplant fruits

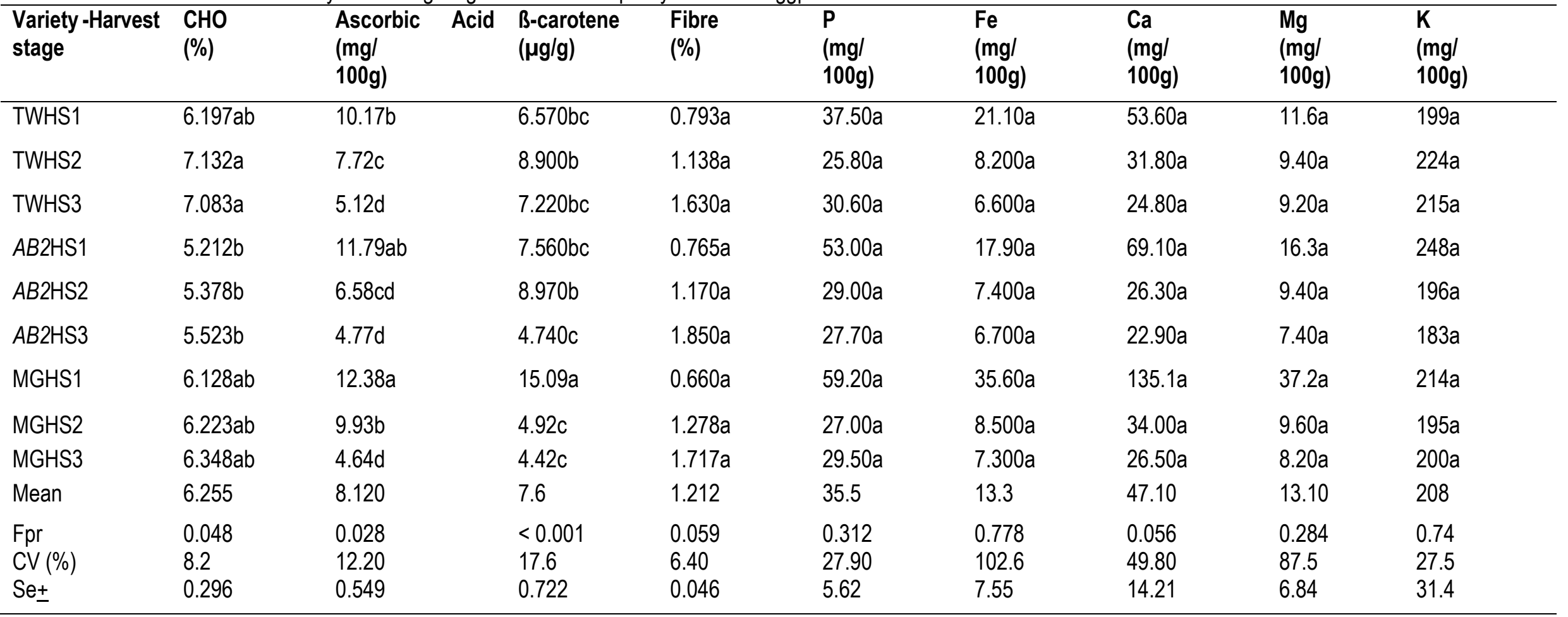

Means bearing the same letter(s) within the column are insignificantly $(\mathrm{P}<0.05)$ different according to Student-Newman-Keuls.

TWHS1 = Harvesting stage 1 on Tengeru white, TWHS2 = Harvesting stage 2 on Tengeru white, TWHS3 = Harvesting stage 3 on

Tengeru white, $A B 2 \mathrm{HS} 1$ = Harvesting stage 1 on $A B 2, \mathrm{AB} 2 \mathrm{HS} 2$ = Harvesting stage 2 on $A B 2, \mathrm{AB} 2 \mathrm{HS} 3=$ Harvesting stage 3 on $A B 2$,

MGHS1 = Harvesting stage 1 on Manyire green, MGHS2 = Harvesting stage 1 on Manyire green, and MGHS3 = Harvesting stage 1 on Manyire green. 


\section{DISCUSSION}

Effect of harvesting stages on fruit yield: The yield assessed based on the number of fruits differed among African eggplant varieties with Tengeru white having the largest number of fruits per hectare. The large number of fruits in this variety was possibly due to its vigorous growth habit coupled with early-developed spreading canopy (Chadha, 2006). Previous studies have also reported a larger number of fruits per plant in tall eggplant varieties with well spread canopies than on cultivars with compact canopies (Abney, 1997; Inglese et al., 2002). The number of fruits per hectare decreased from harvesting stage 1 onwards. The larger number of fruits in harvesting stage 1 was probably due to the activation of more flower initiation caused by early fruit harvesting. A similar finding was reported in Zucchini fruits cultivar "Astra" whereby early harvested plants produced large number of fruits than the late harvested ones (Biesiada et al., 2007). Fruits retention on the plant or extension of fruit harvesting interval has been reported to reduce the final total number fruits on mandarin (Munoz-Fambuena et al., 2011). Hormonal factor and increased competition for nutrients as fruits grow have been reported to be the major cause of fruit number variation (Munoz-Fambuena et al., 2011). On the contrary, the increase in number of fruits on variety Manyire green from harvesting stage 2 to harvesting stage 3 was possibly due to its delayed fruit maturation coupled with an efficient photosynthesis. High photosynthetic rate increases the plant ability to accommodate the increased crop load (CorelliGrappadelli and Lakso, 2004). The decrease in yield (t/ha) from harvesting stage 2 to harvesting stage 3 in variety Tengeru white and $A B 2$ was associated with the decrease in their number of fruits, and was possibly caused by increasing degradation of fruit carbohydrate as a result of fruit senescence. Several reports have shown a decrease in fruit weight with maturity and storage due to the breakdown of polysaccharide into simple sugars and water (Pila et al., 2010; Finger et al., 1995). CorelliGrappadelli and Lakso (2004) associated the decrease of apple fruit weight at late harvest maturity with reduced photosynthetic carbon supply caused by leaf aging, senescence and abscission. On the contrary, the increased yield in variety Manyire green from harvesting stage 2 to harvesting stage 3 was probably due to the continued increase in number of fruits. This trend was associated with the late maturity nature of the variety Manyire green (Chadha, 2006) possibly coupled with slow carbohydrate deterioration (Inglese et al., 2002) and high photosynthetic assimilates at the particular stages of maturity (Corelli-Grappadelli and Lakso, 2004).
Furthermore, the inverse relationship between yield in terms of tons per hectare and number of fruits per hectare observed among the African eggplant variety was probably due to genetic makeup and the fruit weight compensatory effect occurring along the fruit development as reported by Corelli-Grappadelli and Lakso (2004) in apple fruits.

Effect of harvesting stages on fruit nutritional quality : The observed variation in both carbohydrate content between the African eggplant varieties was probably due to their difference in genetic makeup. Similar variation in carbohydrate content was earlier reported among five varieties of water chestnut fruits (Chowdhury et al., 2004). The observed increase in carbohydrate from harvesting stage 1 to harvesting stage 2 in variety Tengeru white was due to varietal genetic makeup as these varieties showed a constant trend of carbohydrate content across harvesting stages. Chowdhury et al. (2004) also reported an increase in total carbohydrate content from anthesis to fruit maturity on water chestnut variety 'Haldipada green'. Fruit vitamin $\mathrm{C}$ and $\mathrm{B}$-carotene contents decreased along the fruit developmental stages. A similar decrease in ascorbic acid and ßeta carotene was reported on leek (Biesiada et al., 2007), kiwi fruits (Clark and Smith, 1988, Ampomah-Dwamena et al., 2009;), citrus and pears (Lee and Kader, 2000). Moreover, Pila et al. (2010) reported a decrease in ascorbic acid in tomato fruits as an indicator of fruit senescence. The difference in ascorbic acid contents among Manyire green, $A B 2$ and Tengeru white was due to their difference in genetic make-up. The observed decrease in beta-carotene content from harvesting stage 1 to harvesting stage 2 on variety Manyire green was probably caused by genetic makeup. Similarly, Ampomah-Dwamena et al. (2009) reported kiwi fruit genotypes and fruit developmental stages as the determinant factors for both total carotenoids and betacarotene accumulation on kiwi fruits. Likewise, the observed increase in beta carotene content on variety Tengeru white and $A B 2$ from harvesting stage 1 to harvesting stage 2 and decrease from harvesting stage 2 to harvesting 3 was associated with variety and harvesting stage interaction. Burger et al. (2008) also reported a similar increase in beta-carotene content on musk melon fruits from anthesis to fruit maturity. The observed decrease in fruit mineral contents (iron, phosphorus, calcium, sodium and magnesium) with fruit development stages was probably due to the variability in plant nutrient uptake. Likewise, kiwi fruits have been reported to have higher calcium mineral content at their early than at late stages of development due to higher 
rate of calcium uptake (Xiloyannis et al., 2001). The constantly lower content of iron, phosphorus and magnesium minerals at advanced stages of the fruit development was probably related to their lower rate of absorption from the soil. Mineral availability in plant is reported to be affected among other things, by plant genetic makeup and harvesting stages (Ismail et al., 2011). The observed increase in fruit fibre content along

\section{CONCLUSION AND RECOMMENDATION}

Yield of African eggplant in terms of number of fruits per hectare can be decreased by harvesting the fruits at immature stage while yield in terms of metric tonnes per hectare can be increased by harvesting fruits at later stage of maturity. However, this trend varies with variety whereby variety Tengeru white and $A B 2$ produce lower yield in tons per hectare at harvesting stage 3 than at harvesting stage 2. Ascorbic acid, beta-carotene, $\mathrm{Ca}, \mathrm{P}$, $\mathrm{Na}$ and $\mathrm{Fe}$ contents can be increased by harvesting fruits at immature stage while carbohydrate and fruit fibre contents can be increased by harvesting the fruits later stage of maturity. This response varies with varieties as variety $A B 2$ and Tengeru white produce the highest betacarotene content at stage 2 of fruit maturity. Fruit carbohydrate content are higher on variety Tengeru white the fruit development stages was probably due to the increased biosynthesis and accumulation over time of fibre components like cellulose, hemicelluloses and pectin. Similar trend was also reported on citrus cv. Novel orange that showed an increase in dietary fibre contents with fruit maturity and adverse weather conditions (Xiuli and Guanlun, 2007).

and Manyire green than on AB2. However, carbohydrate content increases with fruit development on variety Tengeru white. The findings from this study provide evidence that harvesting African eggplant fruits at stage 1 of fruit maturity is suitable for increasing yield in number of fruits per hectare and increasing vitamins and minerals contents while harvesting stage 2 is recommended for increasing fruit beta-carotene content, carbohydrate and fibre contents. As the yield trend varies with varieties, it is recommended that each variety should be harvested at its own fruit maturity stage. Further studies are required to determine yield and nutritional quality of different local varieties of African eggplant at different fruit harvesting stages.

\section{ACKNOWLEDGEMENT}

The authors are thankful to the Alliance for Green Revolution in Africa (AGRA) for financing this study.

\section{REFERENCES}

Abney, T. D. and Russo, V. M. (1997). Factors affecting plant height and yield of Eggplant. Journal of Sustainable Agriculture 10 (4): 37 - 48.

Ampomah-Dwamena, D., McGhie, T., Wibisono, R., Montefiori, M., Hellens, R. P. and Allan, A. C. (2009). The kiwifruit lycopene beta-cyclase plays a significant role in carotenoids accumulation in fruit. Journal of Experimental Botany 60 (13): 3765 - 3779.

Asian Vegetable Research and Development Center (AVRDC). (2003). African Eggplant- Fact sheet. [http://www.avrdc.org/LC/indigenous/afr_eggpla nt.html] site visited on 15/05/2010.

Biesiada, A., Kolota, E. and Adamczewska-Sowinska, K. (2007). The effect of maturity stage on nutritional value of Leek, Zucchini and Kohlrabi. Vegetable Research Bulletin 66: 39 - 45.

Burger, Y., Tadmor, Y., Lewnsohn, E., Meir A., Sa'ar, U., Katzir, N. Paris, H. S. and Schafter, A. A. (2008). Melon fruit colour, more than just looks. In: Proceedings of the ix th EUCARTIA meeting on genetics and breedings of cucurbitaceae, (Edited by Pitrat, M.), 21-24 May, 2008. INRA, Avignon, France. pp. 529 - 534.

Chadha, M. L. (2006). AVRDC's experiences within Marketing of Indigenous Vegetables - A Case Study on Commercialization of African Eggplant. AVRDC, Tanzania. [http://www.underutilizedspecies.org/Documents /PUBLICATIONS/iv_chadha_paper.pdf] site visited on 01/06/2010.

Chowdhury, S. R., Sahoo, N. and Verma, N. H. (2004). Change in fruit size, fruit dry matter and carbohydrate composition at different stages in developing water chestnut fruit. Journal of Aquatic plant management 42: 99 - 103.

Corelli-Grappadelli, L. and Lakso, A. N. (2004). Fruit development in deciduous tree crops as affected by physiological factors and environmental conditions. Acta Horticulturae 636: 425 - 441.

Finger, F. I., Pschuman, R. and Barros, B. S. (1995). Effect of water loss on respiration, ethylene 
production and ripening of banana fruit. Brazilian Journal of Plant Physiology 7 (1): 115 - 118.

Hornal, D., Timpo, S. and Guillaume, G. (2007). Marketing of Underutilized crops: The case of the African egg (Solanum aethiopium) in Ghana. [http://www.underutilizedspecies.org/Documents IPUBLICATIONS/african_garden_egg.pdf] site visited on 21/02/2010.

Ismail, F., Anjum, M. R., Mamon, A. N. and Kazi, T. G. (2011). Trace metal contents of vegetables and fruits of Hyderabad retail market. Pakistan Journal of Nutrition 10 (4): 365 - 372.

Inglese, P., Caruso, T., Gugliuzza, G. and Pace, L. S. (2002). Crop load and rootstock influence on dry matter partitioning in tree of early and late ripening peach cultivars. Journal of American Society Horticultural Science 127 (5): 825 - 830.

Kader, A. A. (1986). Effect of postharvest handling procedures on tomato quality. Acta Hort culturae 190: 209 - 221.

Kader, A. A. (1996). Maturity, ripening, and quality relationships of fruit vegetables. Acta Hort culturae 439: 249 - 255.

Kader, A. A. (1999). Fruit maturity, ripening and quality relationships. Act Horticulturae 485: 203 - 208.

Kader, A. A. (2008). Perspective flavour quality of fruits and vegetables. Journal of the Science of food and Agriculture 88: 1963 - 1868.

Lee, S. K. and Kader, A. A. (2000). Pre-harvesting and postharvest factors influencing vitamin $\mathrm{C}$ content of horticultural crops. Journal of Postharvest Biology and Technology 20: 207 - 220.
Munoz-Fambuena, N., Mesejo, C., Gonzalez-Mas, M. C., Primo-Millo, E., Agusti, M. and Iglesias, D. J. (2011). Fruit regulates seasonal expression of flowering genes in alternate-bearing 'Moncada' Mandarin. Annals of Botany 108: 511 - 519.

National Research Council of the National academies. (2006). Lost crops of Africa- Volume II Vegetables. National Academis of Science. National academies Press., Washington. 352pp.

Pila, N., Gol, N. B. and Rao, T. V. R. (2010). Effect of postharvest treatments on physio-chemical characteristics and shelf life of tomato (Lycopersicon esculentum Mill.) fruits during storage. American Eurasian Journal of Agriculture and Environmental Science 9 (5): $470-479$.

Seki, T. (1990). Laboratory Manual for Food Analysis. Technical cooperative project of Jomo kenyatta University College of Agriculture and Technology, Kenya. 68pp.

Xiloyannis, C., Celano, G., Sebastiani, L. and Minnocci, A. (2001). Water relations, Calcium and Potassium concentration in fruits and leaves during annual and growth in mature Kiwifruit plants. Acta. Horticulture 564: 129 - 134.

Xiuli, Z. and Guanlun, Z. (2007). Studying of dietary fibre change of Novel orange [(Citrus sinesis $(L)$. Osb.) During Fruit Development and Maturation]. American - Eurasian Journ6599 | $P$ a $g$ e al of Environmental Science 2 (5): 581 586. 